Central Washington University

ScholarWorks@CWU

All Faculty Scholarship for the College of the Sciences

College of the Sciences

4-12-2019

\title{
Radiative Forcing by Dust and Black Carbon on the Juneau Icefield, Alaska
}

\author{
Sonia A. Nagorski \\ University of Alaska, Southeast \\ Susan D. Kaspari \\ Central Washington University \\ Eran Hood \\ University of Alaska, Southeast \\ Jason B. Fellman \\ University of Alaska, Southeast \\ S. McKenzie Skiles \\ University of Utah
}

Follow this and additional works at: https://digitalcommons.cwu.edu/cotsfac

Part of the Climate Commons, and the Geology Commons

\section{Recommended Citation}

Nagorski, S. A., Kaspari, S. D., Hood, E., Fellman, J. B., \& Skiles, S. M. K. (2019). Radiative forcing by dust and black carbon on the Juneau Icefield, Alaska. Journal of Geophysical Research: Atmospheres, 124, 3943-3959. https://doi.org/10.1029/2018JD029411

This Article is brought to you for free and open access by the College of the Sciences at ScholarWorks@CWU. It has been accepted for inclusion in All Faculty Scholarship for the College of the Sciences by an authorized administrator of ScholarWorks@CWU. For more information, please contact scholarworks@cwu.edu. 


\section{JGR Atmospheres}

\section{RESEARCH ARTICLE 10.1029/2018JD029411 \\ Radiative Forcing by Dust and Black Carbon on the Juneau Icefield, Alaska}

Key Points:

- We present the first-known quantification of mineral dust and black carbon on the snow cover of the rapidly diminishing Juneau Icefield

- Surface dust and black carbon mass increased from May to July 2016, and dust dominated $\mathrm{BC}$ in terms of concentration and radiative forcing

- Radiative forcing was significant to the ice field's energy budget in July, potentially advancing melt by days to weeks

Correspondence to:

S. A. Nagorski,

sanagorski@alaska.edu

Citation:

Nagorski, S. A., Kaspari, S. D., Hood, E. Fellman, J. B., \& Skiles, S. M. K. (2019) Radiative forcing by dust and black carbon on the Juneau Icefield, Alaska. Journal of Geophysical Research: Atmospheres, 124, 3943-3959. https:// doi.org/10.1029/2018JD029411

Received 28 JUL 2018

Accepted 19 MAR 2019

Accepted article online 29 MAR 2019

Published online 12 APR 2019

Author Contributions:

Conceptualization: Sonia A.

Nagorski, Susan D. Kaspari, Eran

Hood, Jason B. Fellman, S. McKenzie Skiles

Data curation: Susan D. Kaspari, S. McKenzie Skiles

Formal analysis: Sonia A. Nagorski,

Susan D. Kaspari, S. McKenzie Skiles

Funding acquisition: Sonia $\mathrm{A}$.

Nagorski, Eran Hood, Jason B. Fellman

Investigation: Sonia A. Nagorski,

Susan D. Kaspari, Eran Hood, Jason B.

Fellman, S. McKenzie Skiles

Methodology: Sonia A. Nagorski,

Susan D. Kaspari, S. McKenzie Skiles

Project administration: Sonia A.

Nagorski

Software: S. McKenzie Skiles

Supervision: Sonia A. Nagorski

Validation: Susan D. Kaspari, S.

McKenzie Skiles

(continued)

(C)2019. American Geophysical Union. All Rights Reserved.

\author{
Sonia A. Nagorski ${ }^{1}$ (D), Susan D. Kaspari² ${ }^{2}$, Eran Hood ${ }^{1}$ (D), Jason B. Fellman ${ }^{1,3}$ iD, \\ and S. McKenzie Skiles ${ }^{4}$ iD
}

${ }^{1}$ Environmental Science Program, University of Alaska Southeast, Juneau, AK, USA, ${ }^{2}$ Department of Geological Sciences, Central Washington University, Ellensburg, WA, USA, ${ }^{3}$ Alaska Coastal Rainforest Center, University of Alaska Southeast, Juneau, AK, USA, ${ }^{4}$ Department of Geography, University of Utah, Salt Lake City, UT, USA

Abstract Here we present the first known data set on black carbon (BC) and mineral dust concentrations in snow from the Juneau Icefield (JIF) in southeastern Alaska, where glacier melt rates are among the highest on Earth. In May 2016, concentrations of BC $(0.4-3.1 \mu \mathrm{g} / \mathrm{L})$ and dust $(0.2-34 \mathrm{mg} / \mathrm{L})$ were relatively low and decreased toward the interior of the JIF. The associated radiative forcing (RF) averaged $4 \mathrm{~W} / \mathrm{m}^{2}$. In July, after 10 weeks of exposure, the aged snow surface had substantially higher concentrations of BC $(2.1-14.8 \mu \mathrm{g} / \mathrm{L})$ and dust (11-72 $\mathrm{mg} / \mathrm{L})$ that were not spatially distributed by elevation or distance from the coast. RF by dust and BC ranged from 70 to $130 \mathrm{~W} / \mathrm{m}^{2}\left(87 \mathrm{~W} / \mathrm{m}^{2}\right.$ average $)$ across the JIF in July, and RF was dominated by dust. The associated median snow water equivalent reduction in the July samples is estimated at $10-18 \mathrm{~mm} /$ day, potentially advancing melt on the scale of days to weeks. Aging of the snow surface in summer likely resulted in a positive feedback of melt consolidation, enhanced solar absorption and melting, and further concentration of surface particles. Regional projections of warming temperatures and increased rain at the expense of snow make it likely that summer season darkening will become a more important contributor to the high melt rates on the JIF. Further studies are needed to elucidate the spatiotemporal occurrence of various light-absorbing particles on the JIF, and models of ice field wastage should incorporate their associated RF.

Plain Language Summary In May and July 2016, we collected snow samples from the Juneau Icefield, where glacier melt rates are among the highest on Earth. Analyses of black carbon, a by-product of biomass and fossil fuel burning, and dust, small mineral particles that are deposited on the ice field, indicate that these particles darken the surface enough to be a significant factor in the ice field's melt. Because white snow reflects solar radiation whereas dark particles absorb it, these particles enhance melting of the snow beyond that which is caused simply by warming temperatures. As the length of time between spring and autumn snowfalls expands and light-absorbing particles accumulate at the surface throughout the summer months, the particles are likely to become increasingly important players in the ice field's energy balance. The role of these and other light-absorbing particles should be further investigated and incorporated into melt models.

\section{Introduction}

Freshly fallen clean snow has the highest albedo of any natural surface, making snow-covered glaciers important components in Earth's energy balance (Hansen \& Nazarenko, 2004). Light-absorbing particles (LAPs) such as black carbon (BC), mineral dust, snow algae, and other organic matter accelerate melt rates in many of the world's snow and ice covered regions by lowering snow albedo directly in the visible wavelengths, as well as indirectly in the near infrared wavelengths by accelerating grain coarsening (Qian et al., 2015; Skiles et al., 2018; Warren \& Wiscombe, 1980). When snowmelt is accelerated by LAPs, snow grain size increases, and comparatively, dark glacier ice may be uncovered earlier, setting up a snow albedo feedback that further accelerates absorption of solar radiation and melting (Qu et al., 2014; Xu et al., 2009). In order to improve regional and global understanding of the role of LAP in glacier dynamics and in the global climate system, there is a critical need for studies quantifying LAPs on snow and glaciers in high latitude and altitude ecosystems such as Alaska, where few data exist.

$\mathrm{BC}$ is a product of incomplete combustion during the burning of biomass and fossil fuels. In the atmosphere, $\mathrm{BC}$ is an extremely efficient aerosol species at absorbing visible light, exerting a positive radiative forcing 
Writing - original draft: Sonia A. Nagorski, S. McKenzie Skiles Writing - review \& editing: Sonia A. Nagorski, Susan D. Kaspari, Eran Hood, Jason B. Fellman, S. McKenzie Skiles
(RF) to the climate system second only to carbon dioxide (Bond et al., 2013; Mark G. Flanner et al., 2007; Ramanathan \& Carmichael, 2008). Recent studies have shown that the RF caused by BC deposited on snow and ice surfaces has been increased by orders of magnitude since industrialization in many regions of the world including on Arctic sea ice, the Greenland ice sheet, and glaciers in the Himalayas and European Alps (Holland et al., 2006; Kaspari et al., 2011; McConnell et al., 2007; Painter et al., 2013; Sigl et al., 2018). Modern levels of BC have been identified as significant contributors to the acceleration of snow and glacier ice melt rates, thereby also disrupting glacial melt runoff patterns (Kaspari et al., 2011; Xu et al., 2009; Yasunari et al., 2010).

Likewise, the deposition of mineral dust on snow has been linked to accelerated melt (Painter et al., 2018; Skiles et al., 2012). Although studies have shown that dust is 30- to 50-fold weaker than BC in reducing snow albedo (Warren \& Wiscombe, 1980), it can exert a stronger role in RF on snow surfaces in regions where it occurs in relatively high abundance (Skiles et al., 2018; Skiles \& Painter, 2017). For example, on the Mera glacier in the Nepalese Himalayas, dust reduced albedo by $40-42 \%$, creating a stronger RF than BC (Kaspari et al., 2014). In the European Alps, mineral dust from both local sediment sources and remote sources such as the Saharan desert has similarly decreased albedo on the rapidly retreating glaciers (Gabbi et al., 2015; Oerlemans et al., 2009). In the San Juan Mountains in Colorado, USA, the deposition of desert dust was found to decrease snow cover duration by 18-52 days (Skiles et al., 2012). On Iceland's largest ice cap, dust deposition explained 38-42\% of the snowmelt in 2012 (Wittmann et al., 2017). A study of albedo on the Gulkana glacier in central Alaska found a negative correlation between mineral dust mass and measured surface albedo (Takeuchi, 2009). Mineral dust can be sourced from local peri-glacial weathering products as well as from remote sources. Long-range dust comes from both natural processes and anthropogenic disturbance of soils, such as land cultivation for agriculture and grazing, deforestation, erosion, and drying of soils from rising atmospheric temperatures, particularly in arid and semiarid climates (Asner et al., 2004; Tegen et al., 1996).

Glaciers in Alaska and adjacent parts of Canada currently account for some of the fastest glacier melt rates and the largest mountain glacier contribution to sea level rise on Earth (Gardner et al., 2013; Larsen et al., 2015; Radić et al., 2014). However, data on dust, BC, and other LAPs on mountain glaciers in Alaska are sparse, which hinders estimation of their contributions to the high rates of glacier ice melt in the region. Here we elucidate the role of $\mathrm{BC}$ and dust as potential contributing factors driving accelerated glacier melt in the Coast Mountains of southeast Alaska, where, to our knowledge, no such data exist. We characterized the spatial distribution of BC and dust concentrations at 8-10 locations covering approximately $600 \mathrm{~km}^{2}$ of the Juneau Icefield (JIF) in late spring and midsummer. We used BC and dust data to model the resulting snow albedo perturbation and RF and to estimate their contribution to accelerated snowmelt on the JIF. This effort represents an important step toward understanding how BC and dust deposition may be impacting rates of glacier volume loss from glaciers and ice fields in the rapidly changing Coast Mountains of southeast Alaska.

\section{Materials and Methods}

\subsection{Site Description}

The focus of our study was the southern portion of the $3,800 \mathrm{~km}^{2}$ JIF, the fifth largest ice field in the Western Hemisphere that includes about 50 outlet glaciers. The city of Juneau lies between a coastal island archipelago and the western edge of the JIF (Figure 1) and has a cool, maritime climate with a mean temperature of $4.7^{\circ} \mathrm{C}$. Mean annual precipitation at sea level is $1.4 \mathrm{~m}$, although snow water equivalent (SWE) accumulation at high elevations on the ice field is approximately $10 \mathrm{~m} /$ year (Miller \& Pelto, 1999). Precipitation on the JIF is mainly derived from large frontal storms that form in the northern Pacific Ocean and move eastward across the Gulf of Alaska and into Southeast Alaska and Canada. Peak precipitation occurs during fall and early winter (September-January).

Potential sources of BC to the JIF may be both local and long range. Local sources include wood burning stoves and fossil fuel combustion products from urban, transportation, and industrial sources in the Juneau area, where there are no emissions regulations on vehicles. Although only 32,000 people live in Juneau, approximately 1 million tourists arrive each summer on diesel-powered cruise ships, and many are further transported on smaller boats, helicopters, float planes, and buses. Juneau's electricity is 


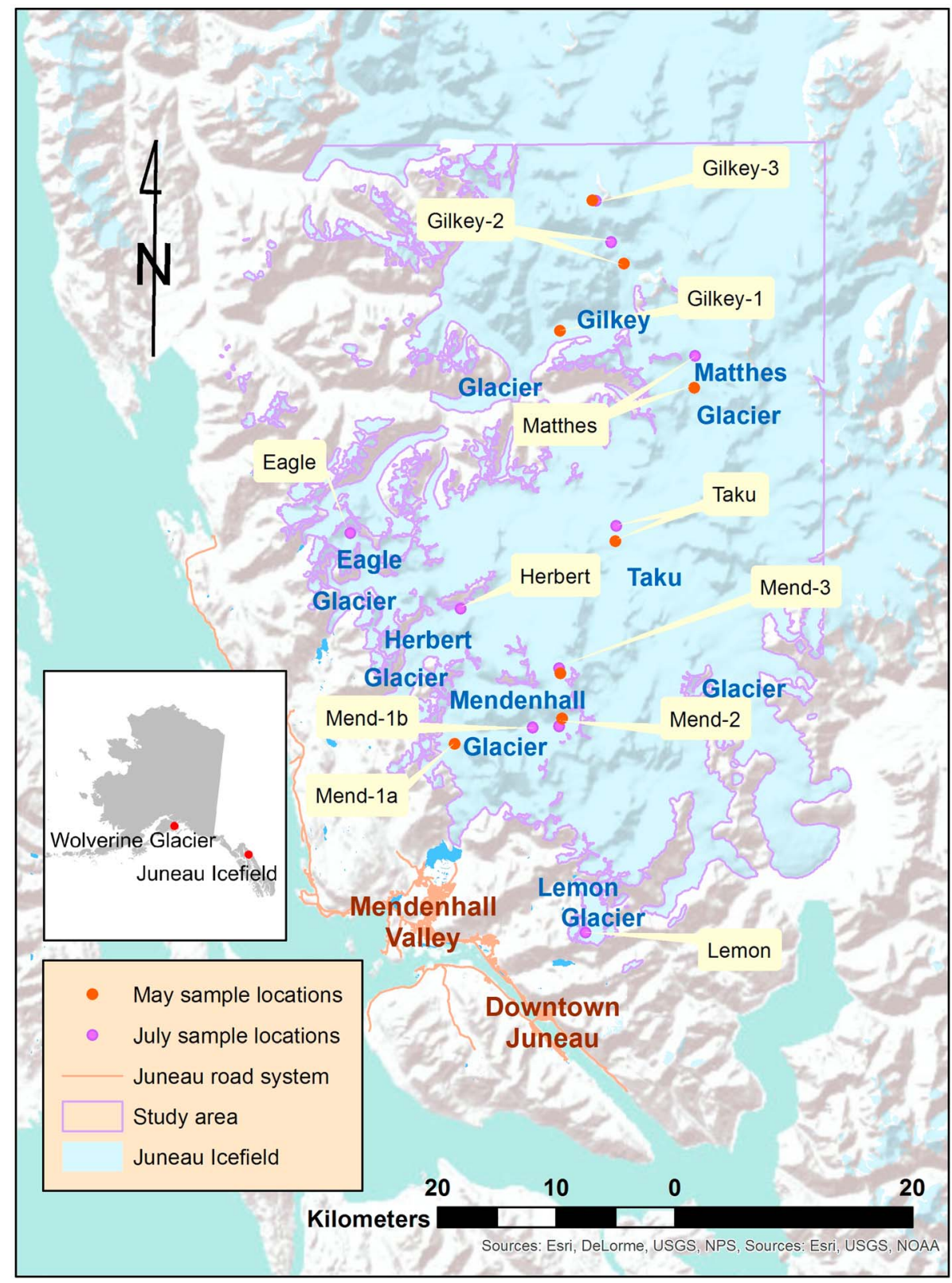

Figure 1. Location map showing the portion of the Juneau Icefield sampled, with glacier names, sample site locations from both sampling events, and location of the urbanized Mendenhall valley and downtown Juneau. Inset map of Alaska shows the location of the Juneau Icefield in the southeast and the Wolverine glacier in the southcentral region of Alaska.

derived entirely from hydropower, and the city has been in compliance with EPA standards for particulate matter since 2009 (ADEC, 2009).

Long-range sources of $\mathrm{BC}$ and dust to the JIF may include fossil-fuel combustion sources and land use changes in upwind regions such as east Asia. Dust and other particulates can be transported across the Pacific Ocean along major atmospheric currents (Bond, 2004; Bond et al., 2007; Hadley et al., 2007). Evidence of this type of long-range pollution comes from models and direct observations of distantly sourced $\mathrm{BC}$, related industrial emissions, and dust in the Arctic region and along the west coast of North America (Jaffe et al., 2003; Koch, 2005; Yu et al., 2008). Previous carbon cycling research in the region demonstrated that fossil fuel combustion by-products are a quantitatively important source of organic carbon deposition to the JIF (Stubbins et al., 2012). Local sources of dust are not quantified but are likely dominated by 
weathering products on recently deglaciated and exposed bedrock and soils along valley slopes, and accumulations of loose, easily erodible glacial moraine and outwash sediments.

\subsection{Field Data Collection}

We collected snow samples on the JIF on 11 May and 18 July 2016. We targeted the May samples as a reference period for fresh snow deposits, and the July samples as summer-aged snow. The May sampling event on the JIF took place 4 days after delivery of snow from a storm system moving in off the Pacific Ocean. The second sampling event occurred in midsummer, at the peak of tourist activity and following 2 weeks of very low precipitation (only $2.3 \mathrm{~mm}$ cumulatively from July 3-18) and an average maximum daily temperature of $21.4{ }^{\circ} \mathrm{C}\left(5^{\circ} \mathrm{C}\right.$ warmer than average for this time period) at sea level, based on National Weather Service climate data from the Juneau International Airport. Average wind direction between the two sampling events was $175^{\circ}$ at Juneau airport, indicating a predominance of southerly flow. Additionally, on 5-6 May 2016, we opportunistically collected a smaller set of samples of several-day old snow at four sites (with five replicates of BC, and one dust sample, at each) on the Wolverine glacier, $700 \mathrm{~km}$ away in the Coast Mountains on the Kenai Peninsula, in order to gain some greater regional context for BC and dust values in fresh snow. Wolverine glacier was not resampled in July.

The sampling design targeted sites at variable distances from the urban centers of Juneau, and in particular from the focused tourist activity around the Mendenhall glacier. In May, we chose three progressively higher elevation sites on each the Mendenhall glacier (closer to urban sources) and the Gilkey glacier (a more remote glacier), and two more sites in the interior of the JIF: Taku and Matthes. The Mendenhall and Gilkey sites are denoted as 1a, 2, and 3, with numbers increasing with elevation (see map). In July, we revisited (within $<2 \mathrm{~km}$ ) six of the eight May sites, but Mendenhall 1a and Gilkey 1 were not sampled because all the snow from the previous winter melted between May and July and glacier ice was exposed. New sites added in July included Herbert Glacier, Eagle Glacier, Lemon Glacier, and a new lower Mendenhall site (called Mendenhall $1 \mathrm{~b}$ ), at the lowest elevation on the glacier where we could collect snow. Herbert, Eagle, Lemon, and Mendenhall-1b are all located at 1,190 \pm 30 m elevation; we targeted a uniform elevation in order to compare spatial differences without potentially confounding elevation-related fractionation of BC/dust deposition.

Snow samples were collected at each site by walking several hundred meters upwind from the helicopter landing site and directly scraping snow along the top $\sim 1 \mathrm{~cm}$ of snow surface into sterile $50 \mathrm{cc}$ centrifuge tubes. At each site, seven individual snow samples (spaced at least $10 \mathrm{~m}$ apart) were collected for replicate $\mathrm{BC}$ analyses in order to ascertain within-site variability. We also used acid-cleaned polyethelyene scoops to collect triplicate snow samples in plastic Whirlpak bags for quantification of mineral dust and organic carbon. Clean polypropylene gloves were worn during sampling. We dug snow pits at six sites in May to $240 \mathrm{~cm}$ and collected depth integrated samples every $30 \mathrm{~cm}$ in order to characterize depth-related changes of LAPs in the snowpack. During the May campaign, we obtained 56 surface snow samples and 48 samples from snowpits across the 8 sites. Snowpit depths included snow no older than about 1-3 months, based on annual accumulation depths. For the July campaign, we collected 70 surface snow samples from 10 sites, and snow pit samples to $1 \mathrm{~m}$ (25 cm increments) at only two sites (Mendenhall-2 and Taku; Figure 1) to focus our efforts more on spatial characterization of the snow surface.

\subsection{Laboratory Analysis}

Snow samples were kept on ice in coolers until returned to the laboratory at University of Alaska Southeast in Juneau, where samples were stored at $-20{ }^{\circ} \mathrm{C}$. Samples were subsequently sent frozen and on ice to Central Washington University, although about two thirds of the samples were partially to fully thawed during the overnight transport. Samples that underwent some degree of thawing did not come from any particular locations on the ice field. Limited data from other studies indicate that freeze-thaw cycles can result in reduced $\mathrm{BC}$ concentrations, particularly when samples are warmed to room temperature (e.g., Schwarz et al., 2013; Wendl et al., 2014), which was not the case for our samples. Comparing all frozen $(n=22)$ samples to those variably thawed $(n=57)$ in our study showed no significant difference in BC concentrations (Mann-Whitney rank sum test $p=0.289$ ). At Central Washington University, samples were thawed and sonicated for $10 \mathrm{~min}$ just prior to analysis. Samples were agitated with a magnetic stir bar during sample measurement, and the liquid sample was pumped using a peristaltic pump to a Cetac Marin 5 nebulizer 
and measured for BC concentration using a wide range Single Particle Soot Photometer, providing a measurement of BC particles between 80 and 1,000 $\mathrm{nm}$. Further details on the methodology are provided in Kaspari et al. (2015) and Wendl et al. (2014). Briefly, photometers are used to determine the thermal radiation of individual BC impurities as they vaporize while crossing a YAG laser. The laser-induced incandescent light produced by the vaporization is linearly proportional to the particle's mass (Stephens et al., 2003). By integrating the mass of BC impurities with monitored liquid and airflows, BC concentrations within liquid samples were determined. Measured BC concentrations were calibrated based on daily Aquadag standards. Samples with concentrations that exceeded $10 \mu \mathrm{g} / \mathrm{L}$ were diluted to fall within the range of the daily calibration. The values reported herein are blank corrected. Replicate analysis of BC concentrations on the same samples yielded an average and maximum difference of $3.6 \%$ and $4 \%$, respectively.

Total impurity concentrations were determined at University of Alaska Southeast on a second set of samples that were thawed and vacuum-driven through preweighed $0.45-\mu \mathrm{m}$ Millipore filters that were later dried overnight and reweighed, yielding values of the total concentration of all particles $>0.45 \mu \mathrm{m}$. It is possible that there were dust and $\mathrm{BC}$ particles not captured by the filter, but this was not measured or accounted for in this study. Results from previous studies suggest that dust particles smaller than $0.45 \mu \mathrm{m}$ are negligible (e.g., Skiles et al., 2017). Replicate analyses of total impurity concentrations yielded an average of 7\% difference between runs, and a maximum difference of $15 \%$. Thermogravimetric analyses were conducted using a Netzsch STA 449. Samples were heated to $800^{\circ} \mathrm{C}$ in a nitrogen atmosphere over $155 \mathrm{~min}$, kept at $800{ }^{\circ} \mathrm{C}$ for $20 \mathrm{~min}$, and then cooled. Thermogravimetric analyses were attempted on samples from all sites, but only Gilkey-2 had enough quantifiable material. Results on that sample indicated that $11 \%$ of the total impurity was combustible organic material. Making the assumption this was true for all samples, we report dust concentrations as $89 \%$ of the total impurity concentration measured gravimetrically. This assumption is reasonable given the lack of visible snow algae and ice worms at our sites (all of which were above tree line) and that the value corresponds well with measured organic carbon content on Gulkana glacier dust of 4.213.5\% (Takeuchi, 2009).

\subsection{Albedo Modeling, RF Calculations, and Uncertainty}

Snow albedo was modeled with the SNow, ICe, and Aerosol Radiation (SNICAR; version 8d off-line; (Flanner et al., 2007), which computes multiple scattering and reflectance from snow and aerosol mixtures across 470 bands $(0.3$ to $5.0 \mu \mathrm{m})$ at 10-nm resolution. Lookup tables are provided for several aerosol types including two types of BC (sulfate coated/uncoated), dust in four size bins, and volcanic ash. The singlescattering optical properties for ice are extracted from lookup tables, which are included for a large range of grain sizes (between $10 \mu \mathrm{m}$ and $5 \mathrm{~mm}$ at $1-\mu \mathrm{m}$ resolution) and have been updated to the most recent ice optical property compilation (Warren \& Brandt, 2008). Snow property inputs include snow effective grain size, snow density, snow depth and layering, and concentrations of LAP. Other inputs include the solar zenith angle, type of atmosphere for irradiance distribution, and ground/substrate albedo. To assess the unique and combined impacts of LAPs, snow albedo was modeled for four scenarios: one without LAPs (clean snow), BC only, dust only, and BC + dust. As described further below, RF is then the difference in absorption between the LAP and clean snow scenarios, which represents the direct surface darkening impact of LAPs.

For this study, input parameters for the May sampling scenario included direct incident radiation under midlatitude clear skies, the solar zenith angle at solar noon on 11 May $\left(51^{\circ}\right)$, snow effective radius of $250 \mu \mathrm{m}$, snow density of $300 \mathrm{~kg} / \mathrm{m}^{3}$, and snow thickness of $5 \mathrm{~m}$. For the July sampling scenario, we again used direct incident radiation under midlatitude clear skies, but the snow effective radius was increased to $1250 \mu \mathrm{m}$, snow density to $550 \mathrm{~kg} / \mathrm{m}^{3}$, and the solar zenith angle for solar noon on $18 \mathrm{July}\left(50^{\circ}\right)$. Grain sizes were not measured in the field, and selected values were guided by snow conditions/age. Snow density values were based on average surface densities from multiple years of mass balance data collected on the Mendenhall glacier (E.Hood, unpublished data). The model was run using averaged values of BC (assuming uncoated variety) and dust from each sampling site. Dust particle size distributions were not measured; thus, here we used previously published partitioning between size bins dust in the San Juan Mountains of southwestern Colorado (3\% D1: 0.1-1 $\mu \mathrm{m}, 6 \%$ D2: 1.0-2.4 $\mu \mathrm{m}, 9 \%$ D3: 2.5-5.0 $\mu \mathrm{m}, 82 \%$ D4: 5.0-10.0 $\mu \mathrm{m}$; Skiles et al., 2017). 
Snow reflectance varies spectrally, and therefore, calculating broadband albedo and estimating RF (in $\mathrm{W} / \mathrm{m}^{2}$ ) requires the spectral distribution of incoming solar radiation. Clear-sky spectral irradiance was modeled for solar noon on 11 May and 18 July between 0.35 and $2.5 \mu \mathrm{m}$ at $10-\mathrm{nm}$ resolution with the Santa Barbara DISORT Atmospheric Radiative Transfer model (Ricchiazzi et al., 1998). From SNICAR albedo and Santa Barbara DISORT Atmospheric Radiative Transfer irradiance spectrally weighted albedo between 0.35 and $2.5 \mu \mathrm{m}$ was calculated by dividing the product of the summation of the product of irradiance and albedo by the summation of irradiance (equation (1)):

$$
\alpha=\frac{\sum_{\lambda=0.35 \mu \mathrm{m}}^{2.5 \mu \mathrm{m}} \mathrm{I}^{*} \alpha_{\mathrm{lap}} \Delta \lambda}{\sum_{\lambda=0.35 \mu \mathrm{m}}^{2.5 \mu \mathrm{m}} \mathrm{I} \Delta \lambda},
$$

where I is the spectral irradiance at the given solar zenith angle, $\alpha_{\text {lap }}$ is the modeled albedo with dust and/or $\mathrm{BC}$ at the same solar zenith angle, and $\lambda$ is the wavelength $(\mu \mathrm{m})$.

$\mathrm{RF}$ was estimated by taking the summation of the product of spectral irradiance and the difference between the spectrally weighted dust/BC albedo and clean snow albedo, which represents the enhanced surface absorption due to $\mathrm{BC}$ and/or dust (equation (2)):

$$
\mathrm{RF}=\sum_{\lambda=0.35 \mu \mathrm{m}}^{2.5 \mu \mathrm{m}} \mathrm{I}^{*}(\Delta \alpha) \Delta \lambda
$$

where $\Delta \alpha=\alpha_{\text {clean }-} \alpha_{\text {lap }}$, which is the difference between clean and particulate laden snow albedo for the same snow grain size, snow density, and irradiance. We report RF for clear-sky solar noon, so these represent maximum daily instantaneous RF.

Because snow is highly reflective in the visible wavelengths, by definition LAPs will always lower snow albedo, but there are a number of sources of uncertainty in constraining the magnitude of this impact via radiative transfer modeling. Inherent snow albedo is determined by LAP content and snow effective grain size; therefore, uncertainties in these two SNICAR forcing variables will propagate through to RF. We recognize that because grain size was not measured, the selected values used in modeling albedo for clean and LAP-containing scenarios may not be representative of actual conditions. We assessed how this would impact modeled albedo values by holding all other inputs constant, including LAP concentrations, and ranging the grain sizes in May from 100 to $600 \mu \mathrm{m}$ and in July from 1,000 to 1,500 $\mu \mathrm{m}$, for the "median" impurity scenario. The uncertainty in reported albedo due to grain size was 7\% higher and 5\% lower for the May snow samples (at 100 and $600 \mu \mathrm{m}$, respectively). For the July snow samples, the uncertainty was $2 \%$ higher and $1 \%$ lower (at 1,000 and 1,500 $\mu \mathrm{m}$ ). To assess the analysis uncertainty for LAP concentrations (3.6\% mean difference for BC, 7\% mean difference for dust) on modeled albedo, we varied the LAP concentrations by this amount for the median scenario, while holding other inputs constant. The uncertainty in reported albedo due to LAP concentrations was lower for cleaner snow in May $(+/-0.03 \%)$, and higher for more contaminated snow in July $(+/-0.3 \%)$. Although snow density is also relevant for snow albedo, a previous uncertainty analysis showed that varying the snow density input to SNICAR does not significantly impact albedo and RF (Kaspari et al., 2014).

There are also important uncertainties in aerosol and snow optical properties associated with reducing model complexity; for example, snow grains and aerosols are nonspherical but are treated as spheres in SNICAR, an imperfect but reasonable assumption for albedo modeling, where nonspherical errors average out when integrating over reflectance and illumination angles. There is also uncertainty related to internal and external aerosol mixing in snow, SNICAR treats aerosols only as external mixtures. Additionally, SNICAR uses representative (i.e., generic) optical properties for aerosols, which in reality are variable and can be altered by atmospheric transport. Skiles et al. (2017) found that using the default dust optical properties in SNICAR resulted in albedo errors of 50-70\%. Additionally, SNICAR has four size bins for dust to account for variation in optical properties due to particle size, but this assumes that these size bins capture the full size distribution, while in reality it typically exhibits a broader range (Skiles et al., 2017). Here our samples did not have enough mass to assess the particles size distribution; to constrain uncertainty in size bin partitioning, we ran SNICAR for the full range of scenarios of dust sizes, from $100 \%$ residing in the smallest size bin to $100 \%$ in the largest size bin for the median scenario in May and July. The uncertainty in albedo was $\sim 0.1 \%$ or less in both May and July and therefore was relatively insignificant compared to the 
uncertainty in grain size and LAP content. We note that there are other aerosol in snow radiative transfer models available that address some of these uncertainties, like the spherical assumption (Libois et al., 2013), but all have their limitations (Tuzet et al., 2017).

There is also uncertainty in irradiance modeling, which determines the magnitude of RF. This is primarily impacted by atmospheric conditions, and we did not attempt to account for changes in aerosol optical depth or clouds in this analysis. If we had calculated full season RF, as opposed to instantaneous RF, an "all sky" approach would be more appropriate. Here we focused primarily on assessing the uncertainty in modeled albedo due to grain size, LAP concentrations, and LAP particle size distribution, but it is important to recognize that there are other potential sources of uncertainty for this approach. Ideally, we would have fieldbased measurements of albedo against which to compare our model outputs, but for this field campaign no spectral albedo measurements were collected. SNICAR outputs have been validated previously, though Skiles et al. (2018) compared outputs to both spectral and broadband albedo over a time series spanning a full melt season and found that there was small but consistent, positive bias in SNICAR albedo (+1\%).

\subsection{Statistical Evaluation}

All statistical analyses were performed in SigmaPlot. Concentration distributions did not pass Shapiro-Wilk normality tests and therefore required nonparametric reporting and analyses. The kriging tool in ArcGIS was used to produce BC spatial distribution models for BC.

\section{Results}

\subsection{May Campaign}

Median site values for BC concentrations in May ranged from 0.4 to $3.1 \mu \mathrm{g} / \mathrm{L}$ in surface snow samples, with an overall median value of $0.9 \mu \mathrm{g} / \mathrm{L}$ (Table 1). At Mendenhall and Gilkey Glaciers, which had multiple sites, the highest median site values ( 3.1 and $1.8 \mu \mathrm{g} / \mathrm{L}$, respectively) were near their termini, closer to the coast. Kriged concentration distributions, based on median values from the eight sites, indicate that BC concentrations in surface snow declined with increasing elevation toward the interior of the JIF (Figure 2a). Across all sites, there was a significant inverse relationship between surface snow BC concentrations and elevation $\left(r^{2}=0.547, p<0.0001\right)$. The median BC concentration in the six JIF snow pits was $0.4 \mu \mathrm{g} / \mathrm{L}$, and snowpit concentrations were significantly lower than those in surface snow (Mann-Whitney rank sum test, $p<0.001)$.

Median dust concentrations on the JIF in May were $<1 \mathrm{mg} / \mathrm{L}$ at all sites and in the snowpits except the lowermost Mendenhall and Gilkey surface sites (Mendenhall-1 and Gilkey-1), where median values were 9 and $34 \mathrm{mg} / \mathrm{L}$, respectively (Table 1).

On the Wolverine Glacier in southcentral Alaska, the four sites had median BC concentrations between 0.1 and $0.8 \mu \mathrm{g} / \mathrm{L}$ (median $0.2 \mu \mathrm{g} / \mathrm{L}$ ) and dust values no higher than $1.8 \mathrm{mg} / \mathrm{L}$ (median = $0.5 \mathrm{mg} / \mathrm{L}$; Table 2).

\subsection{July Campaign}

Median site values of BC concentrations in July varied from 3.7 to $14.8 \mu \mathrm{g} / \mathrm{L}$ in surface snow samples, with an overall median value of $5.1 \mu \mathrm{g} / \mathrm{L}$ (Table 3). Unlike in May samples, BC concentrations in surface snow were not significantly inversely correlated with elevation $\left(r^{2}=0.0017, p=0.791\right)$. Kriged concentration distributions based on median surface snow BC values from the 10 sites revealed several patterns including (1) higher concentrations of $\mathrm{BC}$ north to northeast of the population and tourist center in the Mendenhall Valley, with the highest concentrations at Mendenhall-3 and Herbert Glacier, and (2) generally lower BC toward the interior of the JIF and further from the Mendenhall Valley (e.g., Taku and Gilkey glaciers; Figure 2b). Concentrations of BC in the two snow pits (at sites Mendenhall-2 and Taku), were significantly (13-18 times) lower than BC concentrations at the surface ( $p<0.001$, Mann-Whitney rank sum test).

Median dust concentrations at $10 \mathrm{JIF}$ sites varied between 11 and $72 \mathrm{mg} / \mathrm{L}$ (overall median $=25 \mathrm{mg} / \mathrm{L}$; Table 3). Dust concentrations were highest at Herbert glacier and lowest on the Mendenhall glacier. Dust concentrations did not vary consistently with elevation, as the four sites that were sampled at approximately the same elevation (Mendenhall-1b, Eagle, Herbert, and Lemon) spanned nearly the full range of sample values. Dust was also not correlated with BC $\left(r^{2}=0.0183, p>0.05\right)$. Similar to May, all dust concentrations in the snowpits (dug at Mendenhall-2 and Taku) were $<1 \mathrm{mg} / \mathrm{L}$. 


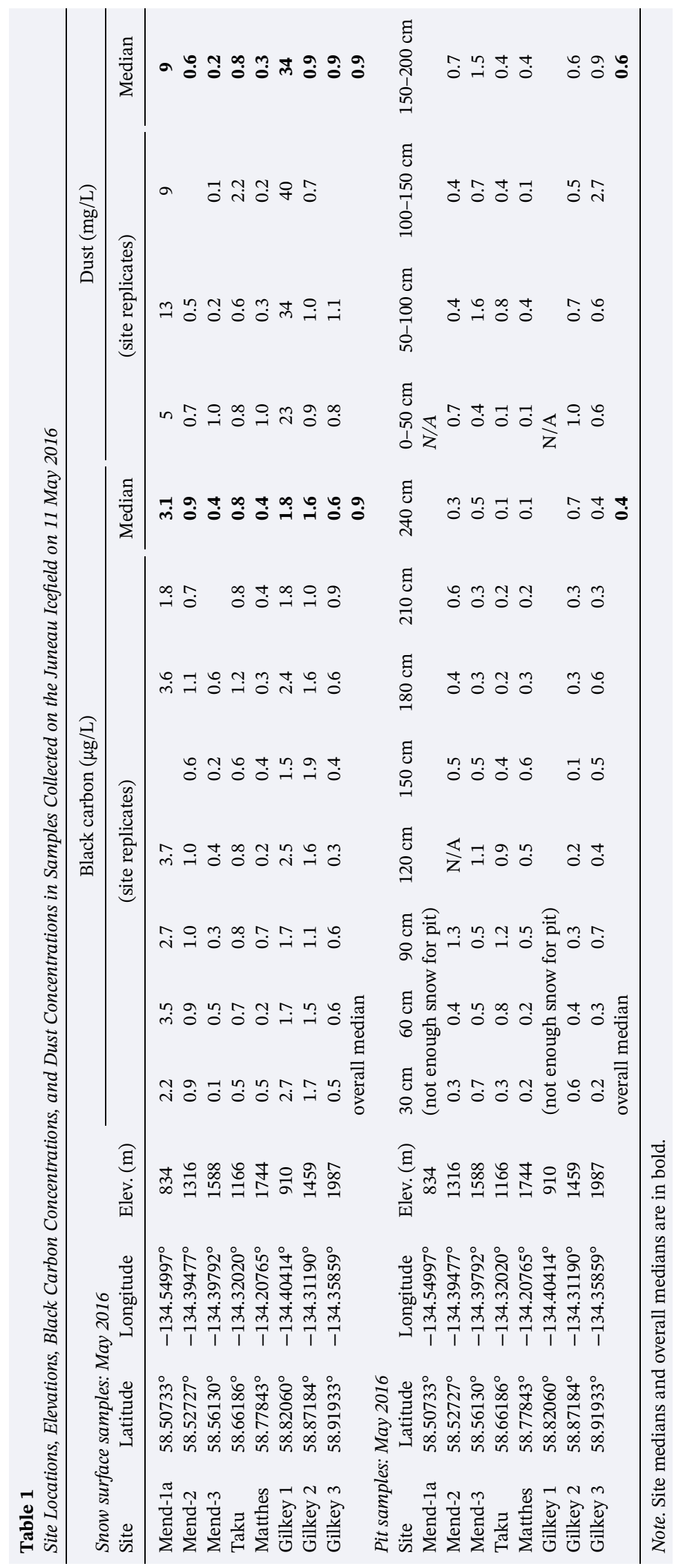



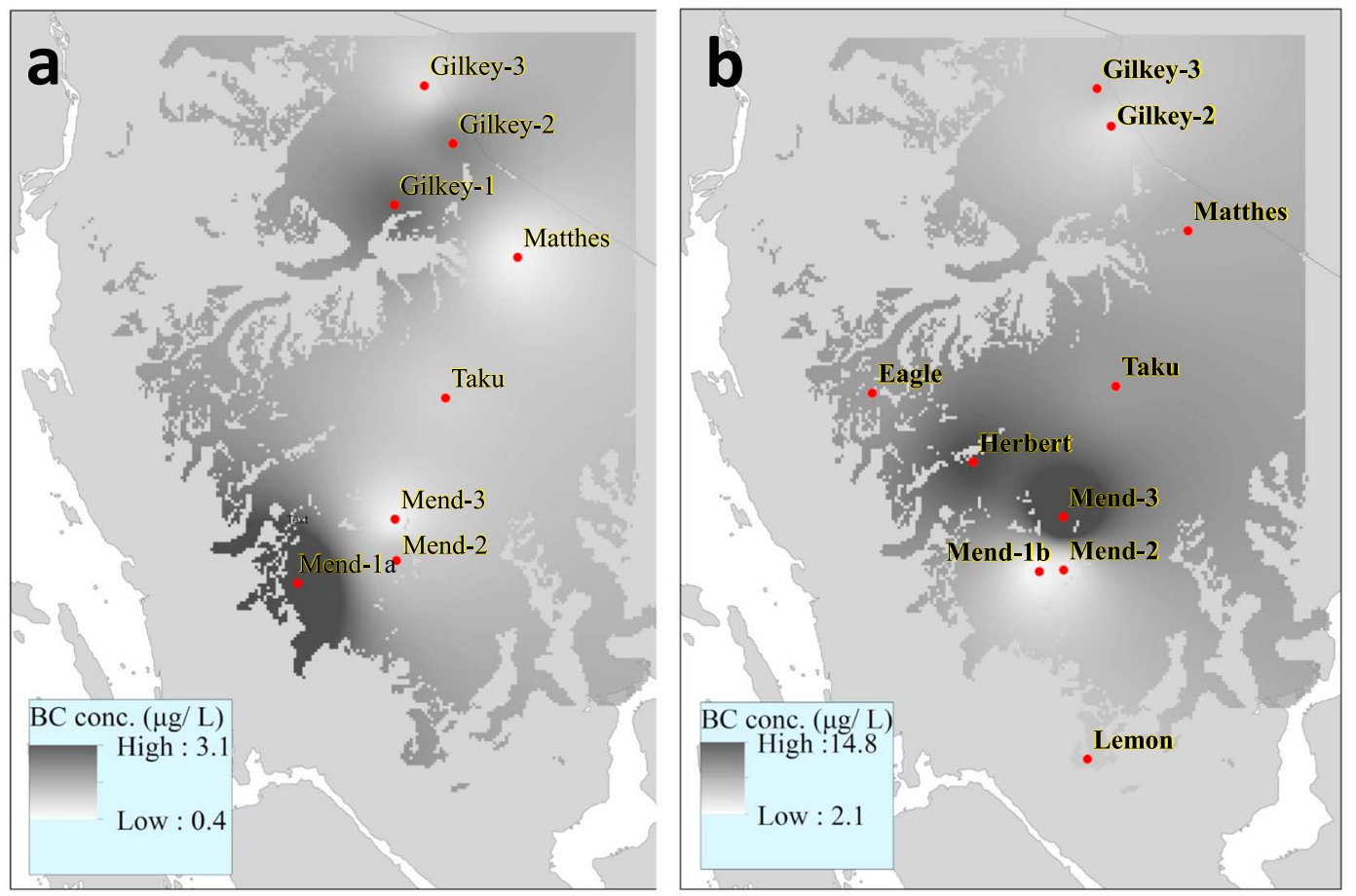

Figure 2. Modeled distribution of black carbon concentrations on our study area portion of the Juneau Icefield, as calculated using the kriging tool in ArcGIS on (a) 11 May 2016 and (b) 18 July 2016. Darkest shades indicate the highest values measured on each of the two sampling dates while the lightest shades correspond to the lowest concentrations. Note the scale value change on the two figures.

\subsection{Snow Impurities During May Versus July}

$\mathrm{BC}$ and dust concentrations in surface snow samples collected in July were significantly higher than those collected in May, both in overall sample comparisons ( $p<0.001$, Mann-Whitney rank sum test) and paired comparisons of the six sites visited both times $(p=0.030$ for $\mathrm{BC}$ and $p=0.004$ for dust, Wilcoxon ranked sign test). However, BC and dust concentrations in snowpits did not differ between May and July ( $p=0.812$ for $\mathrm{BC}$, and $p=0.097$ for dust, Mann-Whitney rank sum test).

Across all sites, July BC concentrations at the snow surface were 2-41 times (average 14 times) higher than in May (Figure 3). The largest change in BC concentrations was at Mendenhall-3, where median values increased from $0.4 \mu \mathrm{g} / \mathrm{L}$ in May to $15 \mu \mathrm{g} / \mathrm{L}$ in July, a 41-fold increase. Also notable were the Matthes and Taku, where BC values in May increased from 0.4 and $0.8 \mu \mathrm{g} / \mathrm{L}$, respectively, to 6-7 $\mu \mathrm{g} / \mathrm{L}$ in July (Tables 1 and 3). In contrast, the smallest increase in BC concentration was at Gilkey-2, where values roughly doubled between May $(1.6 \mu \mathrm{g} / \mathrm{L})$ and July $(3.7 \mu \mathrm{g} / \mathrm{L})$.

Between May and July, dust concentrations at the snow surface increased approximately 20- to 40-fold at the sites visited on both sampling campaigns. The largest increases in dust concentrations were on the Gilkey

Table 2

Black Carbon and Dust Concentrations in Surface Samples Collected on the Wolverine Glacier on 5-6 May 2016

\begin{tabular}{|c|c|c|c|c|c|c|c|c|c|c|}
\hline \multirow[b]{2}{*}{ Site } & \multirow[b]{2}{*}{ Latitude } & \multirow[b]{2}{*}{ Longitude } & \multirow[b]{2}{*}{ Elevation (m) } & \multicolumn{6}{|c|}{ Black carbon (ug/L) } & \multirow{2}{*}{$\frac{\text { Dust }}{(\mathrm{mg} / \mathrm{L})}$} \\
\hline & & & & \multicolumn{5}{|c|}{ (site replicates) } & Median & \\
\hline Wolverine 1 & 60.40992 & -148.876345 & 1351 & 0.1 & 0.2 & 0.2 & 0.1 & 0.1 & 0.1 & 0.2 \\
\hline Wolverine 2 & 60.39631 & -148.907729 & 1032 & 0.3 & 0.5 & 0.2 & 0.4 & 0.2 & 0.3 & $<0.1$ \\
\hline Wolverine 3 & 60.42981 & -148.911715 & 1393 & 0.3 & 0.2 & 0.2 & 0.2 & 0.2 & 0.2 & 0.7 \\
\hline \multirow[t]{2}{*}{ Wolverine 4} & 60.40992 & -148.917982 & 787 & 0.9 & 0.6 & 0.8 & 0.3 & 1.0 & 0.8 & 1.8 \\
\hline & & & & \multicolumn{5}{|c|}{ overall median } & 0.2 & 0.5 \\
\hline
\end{tabular}

Note. Site medians and overall medians are in bold. 


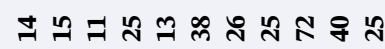

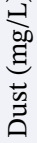
$\Sigma$

ニ

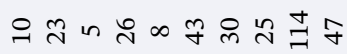

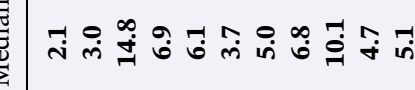

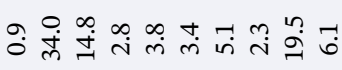

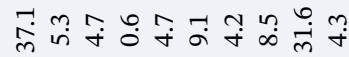
○ लं

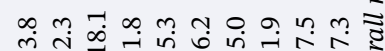

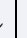

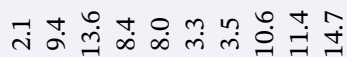

$\exists$ ت



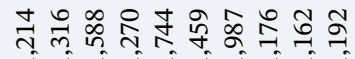

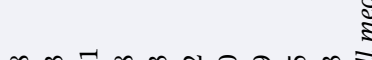
b ํํㅇ ตำ ำ รีำ จุ์

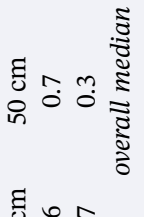
तुํㅇㅇㅇ 이요욤 这 and Taku glaciers, and the smallest changes were on the Mendenhall and Matthes glaciers. The two sites with the highest dust concentrations in May (Mendenhall-1a and Gilkey-1) contained dust concentrations similar to other sites sampled in July; however, these two sites had no remaining snow in July.

\subsection{Radiative Forcing}

In May, albedo and RF modeling using SNICAR showed that albedo reduction by dust and $\mathrm{BC}$ was minor and associated $\mathrm{RF}$ values were relatively low. For a total solar irradiance at noon of $1,038 \mathrm{~W} / \mathrm{m}^{2}$, maximum $\mathrm{RF}$ by dust and $\mathrm{BC}$ ranged from $2.87 \mathrm{~W} / \mathrm{m}^{2}$ (Mendenhall 3) to $33.53 \mathrm{~W} /$ $\mathrm{m}^{2}$ (Gilkey 1) and was $4.47 \mathrm{~W} / \mathrm{m}^{2}$ for the median aerosol scenario (Table 4). All but two sites had RF values for dust and BC that were below $5 \mathrm{~W} / \mathrm{m}^{2}$. The RF at all sites was dominated by dust. Across all scenarios, RF by dust alone was 1.0 to 10.2 times higher relative to BC. Dust RF values ranged from $2.66 \mathrm{~W} / \mathrm{m}^{2}$ (Mendenhall 3) to $33.22 \mathrm{~W} / \mathrm{m}^{2}$ (Gilkey 1) and was $4.05 \mathrm{~W} / \mathrm{m}^{2}$ for the median scenario. RF by BC alone ranged from $2.57 \mathrm{~W} / \mathrm{m}^{2}$ (Mendenhall 3 and Matthes) to $3.90 \mathrm{~W} / \mathrm{m}^{2}$ (Mendenhall 1a) and was $2.83 \mathrm{~W} / \mathrm{m}^{2}$ for the median scenario. The uncertainty in our reported RF, which propagates from uncertainty in modeled albedo, ranges from $30 \%$ to $70 \%$. Because our uncertainties arise from different sources, for example, not measuring grain size versus sensitivity in the concentrations to the measurement technique, we assessed it by comparing the lowest and highest possible RF, from all grain size and concentration/particle size uncertainty scenarios, to the reported RF. The uncertainty is mostly controlled by the uncertainty in grain size. The uncertainty scales inversely with RF values (is higher for lower values), and therefore, we cannot state with confidence that LAPs were having a relevant impact on snow processes or melt for relatively low concentrations in May.

In July, the higher $\mathrm{BC}$ and dust concentrations resulted in a larger reduction in albedo and higher RF values. For a total solar irradiance at noon of $1,088 \mathrm{~W} / \mathrm{m}^{2}$, maximum $\mathrm{RF}$ by dust and $\mathrm{BC}$ ranged from $69.06 \mathrm{~W} / \mathrm{m}^{2}$ (Mendenhall $1 b$ ) to $131.86 \mathrm{~W} / \mathrm{m}^{2}$ (Herbert), and was $87.67 \mathrm{~W} / \mathrm{m}^{2}$ for the median scenario. The uncertainty in RF, again due to grain size, sampled LAP concentrations, and dust particle size distribution, was lower relative to May and ranged from $6 \%$ to $14 \%$. The lower uncertainty and higher values allow us to be more confident that LAPs were having a relevant impact in July. Relative to May, the median RF across sites in July was $\sim 20$ times higher. Similar to its qualities in May, dust consistently dominated $\mathrm{RF}$ in July, ranging from $63.78 \mathrm{~W} / \mathrm{m}^{2}$ (Mendenhall 3) to $129.55 \mathrm{~W} / \mathrm{m}^{2}$ (Herbert), which was 1.34 to 2.94 times higher than RF from BC. The three sites with RF values above $100 \mathrm{~W} / \mathrm{m}^{2}$ (Gilkey 2, Herbert, and Lemon) were the sites with the highest dust concentrations but not necessarily the highest $\mathrm{BC}$ concentrations. $\mathrm{RF}$ from $\mathrm{BC}$ alone ranged from $36.82 \mathrm{~W} / \mathrm{m}^{2}$ (Mendenhall 1) to $47.71 \mathrm{~W} / \mathrm{m}^{2}$ (Mendenhall 3) and was $39.73 \mathrm{~W} / \mathrm{m}^{2}$ for the median scenario.

\subsection{Impact on Melt}

Using the RF, which represents the energy absorbed in the snowpack due to $\mathrm{BC}$ and dust deposition, we make a first-order estimate of the impact of LAP on snowmelt by doing a simple energy analysis across the hour spanning solar noon (i.e., we use the mean clear-sky solar irradiance over the 


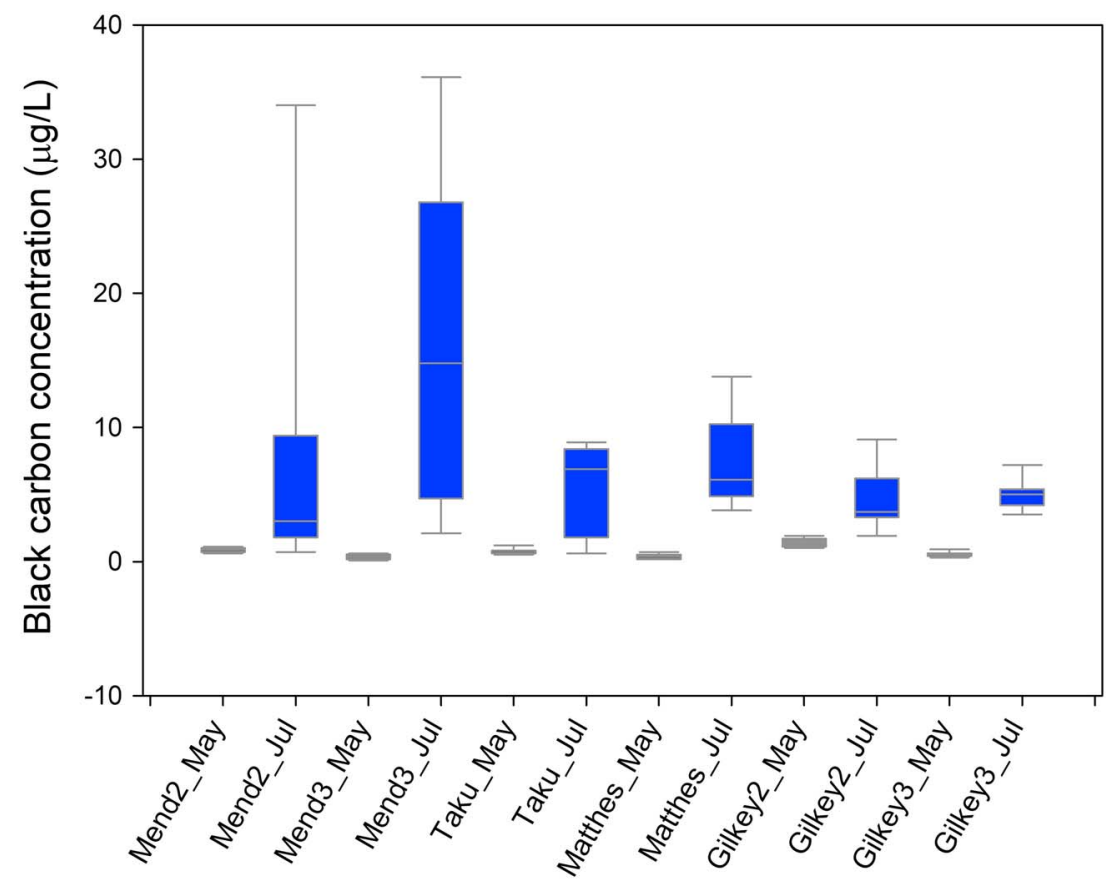

Figure 3. Boxplots showing the distribution of within-site replicate concentrations of black carbon concentrations at the snow surface at the six sites (Mendenhall 2, Mendenhall 3, Taku, Matthes, Gilkey 2, and Gilkey 3) that were visited in both May (gray boxes) and July (blue boxes).

hour spanning solar noon to calculate hourly mean RF). This requires the assumption that the snow cold content is depleted (snow is at $0^{\circ} \mathrm{C}$ ); otherwise, the additional energy would be contributing to raising the temperature of the snow to $0^{\circ} \mathrm{C}$. This assumption is reasonable for the sampling in July, but not in May. The additional melt from LAP RF is estimated by dividing RF by the enthalpy of fusion of water at $0{ }^{\circ} \mathrm{C}$ $\left(0.334 \times 10^{6} \mathrm{~J} / \mathrm{kg}\right)$, to return melt in kilograms per square meter, equivalent to a millimeter of SWE per hour $(\mathrm{mm} / \mathrm{hr})$. Median scenario RF in July translates into a SWE reduction of $0.91 \mathrm{~mm} / \mathrm{hr}$, and for all scenarios the lowest SWE reduction was at Mendenhall $1 \mathrm{~b}(0.74 \mathrm{~mm} / \mathrm{hr})$ and highest at Herbert $(1.42 \mathrm{~mm} / \mathrm{hr})$. By varying the solar irradiance over daylight hours and calculating the daily cycle of RF, a rough estimate of the integrated daily contribution to melt can be made. SWE reduction due to LAP for the median scenario was $12 \mathrm{~mm} /$ day, ranging from $18 \mathrm{~mm} /$ day for Herbert to $10 \mathrm{~mm} /$ day for Mendenhall 1b. For comparison purposes, if the snow were at $0{ }^{\circ} \mathrm{C}$ in May, the daily melt contribution by LAP would have been $0.6 \mathrm{~mm} /$ day for the median scenario and ranged from $0.4 \mathrm{~mm} / \mathrm{day}$ (Mendenhall 3 ) to $5 \mathrm{~mm}$ /day (Gilkey 1).

\section{Discussion}

\subsection{BC and Dust Concentrations}

BC samples from the late spring snow storm in May showed a washout effect along the coast, with decreasing $\mathrm{BC}$ concentrations toward the interior of the JIF, consistent with $\mathrm{BC}$ deposition at other coastal sites (e.g., Babu \& Moorthy, 2002). The aged snow at sites measured in July lacked a discernable coastal washout effect; however, the highest $\mathrm{BC}$ concentrations in midsummer were located downwind of the Juneau urban corridor. Winds in Juneau during the summer typically come from the south, and the average daily wind direction at Juneau International Airport for the period between the two sampling events was $175^{\circ}$, indicating that airflow was generally directed from the high use areas (municipal and vessel sources) into the JIF locations with of highest BC occurrence on the snow. Ice field helicopter tours of the ice field are also particularly common in the same areas. Yet not all sites situated north of Juneau had uniformly elevated BC levels, indicating that localized airflow dynamics resulting from the complex topography of the Coast Mountains likely play a role in BC deposition on the JIF. For example, although 
Table 4

SNICAR-modeled Albedo Values for Clear-Sky Solar Noon at Juneau Icefield Sites Under Scenarios of Zero Impurities; Addition of BC; and Addition of Both BC and Mineral Dust. Radiative Forcing $\left(\mathrm{W} / \mathrm{m}^{2}\right)$ for BC; Dust; and BC Plus Dust

\begin{tabular}{|c|c|c|c|c|c|c|c|c|c|}
\hline & \multirow{2}{*}{$\begin{array}{c}\text { BC conc. } \\
(\mu \mathrm{g} / \mathrm{L})(\mu \mathrm{g} / \mathrm{L})\end{array}$} & \multirow{2}{*}{$\begin{array}{l}\text { Dust conc. } \\
\text { (mg/L) }\end{array}$} & \multicolumn{4}{|c|}{ Albedo (SNICAR model) } & \multicolumn{3}{|c|}{ Radiative forcing (W m-2) } \\
\hline & & & Clean & $\mathrm{BC}$ & Dust & $\mathrm{BC}+$ dust & RF_BC & RF_Dust & RF_BC + dust \\
\hline \multicolumn{10}{|l|}{ May samples } \\
\hline Median & 0.9 & 0.9 & 0.748 & 0.745 & 0.744 & 0.743 & 2.83 & 4.05 & 4.47 \\
\hline Mendenhall 1a & 3.1 & 9.2 & 0.748 & 0.744 & 0.733 & 0.733 & 3.90 & 14.81 & 15.66 \\
\hline Mendenhall 2 & 0.9 & 0.6 & 0.748 & 0.745 & 0.744 & 0.744 & 2.83 & 3.54 & 3.97 \\
\hline Mendenhall 3 & 0.4 & 0.2 & 0.748 & 0.745 & 0.745 & 0.745 & 2.57 & 2.66 & 2.87 \\
\hline Taku & 0.8 & 0.8 & 0.748 & 0.745 & 0.744 & 0.744 & 2.78 & 3.94 & 4.30 \\
\hline Matthes & 0.4 & 0.3 & 0.748 & 0.745 & 0.745 & 0.745 & 2.57 & 3.02 & 3.21 \\
\hline Gilkey 1 & 1.8 & 34 & 0.748 & 0.745 & 0.716 & 0.715 & 3.27 & 33.22 & 33.53 \\
\hline Gilkey 2 & 1.6 & 0.9 & 0.748 & 0.745 & 0.744 & 0.743 & 3.18 & 4.15 & 4.86 \\
\hline Gilkey 3 & 0.6 & 0.9 & 0.748 & 0.745 & 0.744 & 0.743 & 2.67 & 4.18 & 4.45 \\
\hline \multicolumn{10}{|l|}{ July samples } \\
\hline Median & 5.1 & 25 & 0.688 & 0.652 & 0.610 & 0.608 & 39.73 & 85.08 & 87.67 \\
\hline Mendenhall $1 b$ & 2.1 & 14 & 0.688 & 0.654 & 0.626 & 0.625 & 36.82 & 68.04 & 69.06 \\
\hline Mendenhall 2 & 3.0 & 15 & 0.688 & 0.654 & 0.623 & 0.621 & 37.73 & 71.30 & 72.67 \\
\hline Mendenhall 3 & 14.8 & 11 & 0.688 & 0.644 & 0.630 & 0.623 & 47.71 & 63.78 & 71.09 \\
\hline Taku & 6.9 & 25 & 0.688 & 0.650 & 0.610 & 0.607 & 41.35 & 85.32 & 87.90 \\
\hline Matthes & 6.1 & 13 & 0.688 & 0.651 & 0.627 & 0.624 & 40.64 & 66.95 & 69.92 \\
\hline Gilkey 2 & 3.7 & 38 & 0.688 & 0.653 & 0.596 & 0.596 & 38.41 & 100.56 & 101.71 \\
\hline Gilkey-3 & 5.0 & 26 & 0.688 & 0.652 & 0.609 & 0.609 & 39.64 & 85.84 & 87.71 \\
\hline Eagle & 6.8 & 25 & 0.688 & 0.650 & 0.610 & 0.610 & 41.27 & 85.08 & 87.63 \\
\hline Herbert & 10.1 & 72 & 0.688 & 0.648 & 0.569 & 0.569 & 44.06 & 129.55 & 131.86 \\
\hline Lemon & 4.7 & 40 & 0.688 & 0.652 & 0.594 & 0.594 & 39.36 & 102.43 & 103.86 \\
\hline
\end{tabular}

Note. Site medians and overall medians are in bold.

the two lowermost Mendenhall sites (Mend-1b and Mend-2) had the lowest median BC concentrations of all July sites, one of the seven site replicates at each of the sites had among the highest BC concentrations in any sample collected for the entire study $(37.1,34.0 \mu \mathrm{g} / \mathrm{L})$. These results indicate particularly high spatial heterogeneity and complexity, and they underscore the need for detailed sitespecific characterization.

Unlike BC, dust concentrations on the JIF followed no discernable spatial pattern other than enhanced concentrations at sites closest to the glacier termini (Mendenhall 1a and Gilkey 1) in the May samples. The heterogeneity in both BC and dust concentrations at the four sites sampled in July that were roughly at the same elevation indicates that site-specific source variability and melt consolidation processes were more important in controlling the LAP accumulation than simple long-range air mass delivery and fractionation by elevation. More work is needed to evaluate dust distribution, grain size, and composition across the JIF in order to elucidate the roles of local and distant dust sources.

The increase in BC and dust in surface snow from May to July, which was not matched in the snowpit samples, is likely due to a combination of (1) the continued accumulation of LAP at the snow surface due to wet and dry deposition and (2) the process of melt amplification, where previously deposited LAP concentrates at the surface rather than being removed via melt entrainment (Doherty et al., 2013). Dry and warm conditions for 2 weeks prior to our July sampling campaign likely provided ideal conditions for high melt rates of the near-surface snowpack and melt amplification. The process of consolidation of LAP on the snow surface enhances melt rates via surface darkening and snow grain coarsening, setting up a positive feedback in which the enhanced melting further amplifies surface concentrations of LAP (Warren \& Wiscombe, 1980). Melt amplification has been shown to be an important factor in ice melt in other regions of the world such as on the Greenland ice sheet (Goelles \& Bøggild, 2017; Tedesco et al., 2016), glaciers in the Himalayas (Kaspari et al., 2014; Xu et al., 2009; Yasunari et al., 2010), Colorado Rockies (Skiles \& Painter, 2017), Alps (Tuzet et al., 2017), Japan (Aoki et al., 2006), and in several Arctic sites (northern Alaska, Greenland, and Norway; Doherty et al., 2013). 
Data on cryospheric LAPs in Alaska are extremely sparse; the only known prior collections are by Doherty et al. (2010), who analyzed single-surface snow samples from the McCall Glacier in the Brooks Range ( $5.0 \mathrm{ng} / \mathrm{g}$; note that $1 \mathrm{ng} / \mathrm{g}$ is equivalent to $1 \mu \mathrm{g} / \mathrm{L}$ ) and on sea ice near Barrow $(9.0 \mathrm{ng} / \mathrm{g}$ ), which are within the range of July surface snow samples on the JIF. Other reported measurements of snow impurities include dust values on the Gulkana glacier, which are reported not as concentrations in snow but in mass per area of snow surface, and therefore not directly comparable with our values (Takeuchi, 2009), and of snow algae on the Harding Icefield (Ganey et al., 2017; Takeuchi et al., 2006). More broadly, the BC concentrations we measured on the JIF are generally within the range of published values for samples collected across the Arctic, where RF by $\mathrm{BC}$ has been shown to be a contributor to snow and ice melt and appears to explain the underestimation of melt rates calculated by greenhouse gas forcing alone (Flanner et al., 2007; Flanner et al., 2009; Hansen \& Nazarenko, 2004). Median BC concentrations in our JIF samples, which ranged from $0.9 \mu \mathrm{g} / \mathrm{L}$ in May to $5.1 \mu \mathrm{g} / \mathrm{L}$ in July, and in our Wolverine glacier samples $(0.1-0.8 \mu \mathrm{g} / \mathrm{L})$, are low compared with mean observations of surface snow in western (27 ng/g) and eastern Russia (34 ng/g) but similar to mean concentrations in the Canadian and Alaskan arctic ( $8 \mathrm{ng} / \mathrm{g})$ and Greenland (3 ng/g; Doherty et al., 2010). However, cross-study comparisons are confounded to some extent by methodological differences in BC analyses. For example, studies that used an integrating sphere setup (i.e., Doherty et al., 2010) may overestimate BC values and underestimate the associated uncertainty due to the method's sensitivity to other light-absorbing impurities such as dust (Schwarz et al., 2012).

Surface snow BC concentrations on the JIF are also consistent with BC concentrations in a 37-year ice core record from Mt. Waddington in the Coast Mountains of British Columbia, where BC values were consistently $<5 \mathrm{ng} / \mathrm{g}$, with occasional concentration spikes exceeding $20 \mathrm{ng} / \mathrm{g}$ likely as result of regional forest fires (Neff et al., 2012). Forest fires have similarly been shown to impact BC concentrations in snow in northwest Greenland, where the mean BC concentration reached $15 \mathrm{ng} / \mathrm{g}$ in summer 2013 (Thomas et al., 2017), and on the Snow Dome glacier on the Olympic Peninsula in Washington, where BC concentrations in snow postfire were 2 orders of magnitude greater than those we measured on the JIF (Kaspari et al., 2015). Forest fires are not likely to be an important source of BC to the JIF, given that fire return intervals in the coastal temperate rain forest of southeast Alaska typically occur on millennial timescales (Lertzman et al., 2002). Although smoke and aerosols from distant forest fires, such as from interior Alaska, eastern Asia, or interior British Columbia, can occasionally reach the JIF, no known fires were burning in the proximity of the JIF, and there were no known reports of haze during our study period.

\subsection{LAP RF and Ice Field Melt}

Although BC is the most absorptive impurity per unit mass and is 30-50 times more efficient than dust in absorbing solar radiation, the concentration of dust in our samples was 3 orders of magnitude higher than $\mathrm{BC}$, and the two LAPs also have an interactive effect in which they partially diminish one another's individual effects (Kaspari et al., 2011). As a result, dust dominated the albedo reduction and RF associated with LAPs on the JIF (Table 4). This impact was notable in July, with RF by dust alone being 2.1 times greater than that by BC alone for the median scenario. The RF due to dust and BC in the July snow is explained by a combination of their higher concentrations relative to May as well as the grain-size feedback, in which the LAPs accelerate snow grain growth, which in turn further lowers albedo in the longer wavelengths and increasingly allows for amplification of the radiative perturbation by LAPs (Hadley \& Kirchstetter, 2012; Skiles \& Painter, 2017).

Dust sources to the JIF likely include weathering products of exposed rocks on and adjacent to the ice field, and abundant stocks of fine grained, freshly exposed weathered material comprising lateral moraines that are progressively more exposed with glacier thinning and retreat during the melt season (Oerlemans et al., 2009). Mineral dust may also be transported on long-range atmospheric currents, with source areas to Alaska likely residing in East Asia, the source region for dominant air currents (Cottle et al., 2013; Yi et al., 2014; Zhang et al., 2003).

Dust has been implicated as a factor in enhanced snow and ice melt rates globally (Kaspari et al., 2015; Skiles et al., 2018; Skiles \& Painter, 2017; Wittmann et al., 2017). In a study in the Sierra Nevada Mountains in California, where dust concentrations were consistent with those found on the JIF (1-53 mg/L; mean $=12 \mathrm{mg} / \mathrm{L}$ ), dust similarly dominated RF relative to BC (Sterle et al., 2012). The RF values for dust on the JIF are also similar to those found in surface snow samples from Snow Dome in the Olympic 
Mountains in summer 2012 where RF from dust ranged from 37 to $53 \mathrm{~W} / \mathrm{m}^{2}$ (Kaspari et al., 2015). In extreme cases dust has been shown to advance melt by 1-2 months (Skiles et al., 2012), and even at lower concentrations, melt impacts have been shown to scale linearly with dust concentrations (Skiles et al., 2015). In that context, for the JIF concentrations sampled here, dust may accelerate melt on the scale of days to weeks. As outlet glaciers of the JIF continue to thin and retreat, the amount of local dust available for wind erosion and transport will likely increase as bedrock, colluvium, and glacier deposited sediments become more exposed. However, the rapid rates of colonization by vegetation along the JIF, where widespread revegetation of deglaciated landscapes can occur on the timescale of a decade (Knelman et al., 2012), may at least partially mitigate the potential for increased dust deposition in the future.

The LAP-driven reductions in SWE that we document in midsummer on the JIF $(12 \mathrm{~mm} /$ day for the median scenario) are consistent with previous work at Snow Dome in the Olympic Mountains where the average daily enhanced SWE loss was 9-13 mm prior to an adjacent forest fire (Kaspari et al., 2015). Although other studies have implicated LAP as contributing to mass balance loss (Gabbi et al., 2015; Painter et al., 2013; Schmale et al., 2017), the extent to which LAP-driven melt is contributing to volume loss on the JIF is difficult to quantify. Yet we estimate this using the annual summer balance near sites we sampled on the Mendenhall Glacier, which is on the order of $-3 \mathrm{~m}$ of water equivalent (Motyka et al., 2003). For the summer melt season, this equates to an average SWE reduction of about $25 \mathrm{~mm} /$ day, assuming a 4-month melt season. In this context, the LAP-driven SWE reductions we modeled at Mendenhall-1a and Mendenhall-1b, which ranged from $\sim 1 \mathrm{~mm} /$ day in May to $\sim 10 \mathrm{~mm} /$ day in July, have the potential, particularly in midsummer, to make a quantitatively important contribution to glacier volume loss on the JIF in areas that are downwind of dust and BC sources. Moreover, SWE reductions in snow cover on the JIF driven by LAP can contribute to a positive feedback on glacier melt by reducing the temporal duration of snow cover on the ice field, thereby hastening the exposure of low albedo glacier ice.

\section{Conclusions and Future Implications}

Results from our late spring and midsummer sampling campaigns on the JIF show that LAP concentrations, which are generally within the range reported for sites in the Arctic, experienced a twofold to 40-fold increase in BC and dust in surface snow, but not with depth, over 10 weeks of the 2016 summer season. The increase was likely due to a combination of accumulation of dry and wet deposition of LAPs from natural and anthropogenic sources, as well as melt consolidation at the surface. As LAPs aggregate on the snow over the course of the summer melt season, absorbed solar radiation and RF increases due to the albedo decline, setting up a positive feedback of melt, growth of snow grain size, consolidation of LAPs, and further absorption of solar energy and melt.

The influence of LAPs on SWE reduction and RF on the JIF has the potential to increase in the future. Locally, there is ongoing rapid expansion of the cruise ship and tour industries that rely on diesel powered ships, buses, smaller boat transport, and helicopter tours of the JIF (Rain Coast Data, 2018). Dust increases are generally expected from regional areas undergoing rapid deglaciation, a process that exposes abundant fine, loose sediment, produced by glacier scouring and transport (Crusius et al., 2011). Furthermore, there has been a near doubling of atmospheric dust during the twentieth century, likely due to climate change induced drought and human land use practices (Mahowald et al., 2010), and long-range sources of dust and other aerosols from desert landscapes such as those in east Asia may also be significant to the JIF, although the magnitude of their role remains unknown due to lack of geochemical fingerprinting and poorly constrained forecast variables related to wind, precipitation, and vegetation shifts (Yu et al., 2012). In addition, climate change projections for the region indicate that precipitation on the JIF is progressively favored to arrive in the form of rain rather than snow, as average temperatures climb above freezing for longer periods of the year in coming decades (Shanley et al., 2015). These changes will leave darker, summer-aged snow surfaces as well as bare ice surfaces exposed for longer periods during lengthened melt seasons, a process commonly referred to as the snow albedo feedback, which will amplify melt rates. For equivalent concentrations, LAPs impact ice to a lesser degree than snow, because ice is darker; however, LAPs from multiple seasons can accumulate at the ice surface, amplifying associated RF impacts. Moreover, LAP-driven icemelt can initiate positive feedbacks such as ponding and can support microbial growth by providing both water and nutrients. These dynamics are still not well understood; therefore, improving our understanding 
of the seasonal variation of LAPs on snow and ice surfaces on the JIF will be critical for accurately quantifying the RF caused by LAPs and how they may impact the JIF in the future.

A recent projection of the mass balance of the JIF suggests that that roughly two thirds of the volume and area JIF will be lost by the end of the century and that it will be completely eliminated by 2200 (Ziemen et al., 2016). However, the model did not account for the potential role of surface darkening and RF by LAPs on accelerating glacial mass loss, or any future changes in the deposition of LAPs on the JIF. Future work is also needed to quantify the relative importance of RF from microbes, such as snow and glacier algae, on the JIF. Snow algae on the Harding Icefield in Alaska have been shown to exert RF on the order of $15-20 \mathrm{~W} / \mathrm{m}^{2}$ and increase snowmelt by $20 \%$ (Ganey et al., 2017). Thus, accounting for the impact of biological LAPs on the JIF will likely increase the RF associated with abiotic LAPs, which we focused on here. Moreover, dust can enrich nutrients such as phosphorous in deposition regions, such that in a warmer, dustier, future, microbes would be less water and nutrient limited; blooms would occur earlier and cover more area, compounding the impact in perennial snow-covered environments (Skiles et al., 2018).

\section{Acknowledgments}

Funding for this project was provided to support sample analysis by S. D. K., transportation to the sites, and to S. A. N., J. B. F., and E. H. by Alaska EPSCoR (NSF award \#OIA-1208927 and the state of Alaska); by the U.S. Forest Service National Air Resource Management Program and the Tongass National Forest Air Program by the Alaska Climate Adaptation Science Center, and the Alaska Coastal Rainforest Center. Thanks to A. Nathlich for dust filtrations; to M. Dwyer for GIS map work; to A. Bidlack, A. Andrews, and A. Johnson for field assistance; and to the anonymous reviewers who significantly improved the manuscript. S. O'Neel and the USGS Alaska Science Center provided support for sample collection at Wolverine Glacier. The data presented in this manuscript can be obtained in the tables. The SBDART and SNICAR modeling tools are freely available online (https://www.paulschou.com/ tools/sbdart/ and http://snow.engin. umich.edu/).

\section{References}

ADEC. (2009). New data shows Juneau meets federal air quality standards. Alaska Department of Environmental Conservation. Report available at http://dec.alaska.gov/air/anpms/doc-anpms/Juneau_pm2-5_final.pdf

Aoki, T., Motyoshi, H., Kodama, Y., \& Yasunari, T. J. (2006). Atmospheric aerosol deposition on snow surfaces and its effect on albedo. SOLA, 2, 13-016.

Asner, G. P., Elmore, A. J., Olander, L. P., Martin, R. E., \& Harris, A. T. (2004). Grazing systems, ecosystem responses, and global change. Annual Review of Environment and Resources, 29(1), 261-299. https://doi.org/10.1146/annurev.energy.29.062403.102142, https://doi. org/10.1146/annurev.energy.29.062403.102142

Babu, S. S., \& Moorthy, K. K. (2002). Aerosol black carbon over a tropical coastal station in India. Geophysical Research Letters, $29(23), 2098$. https://doi.org/10.1029/2002GL015662

Bond, T. C. (2004). A technology-based global inventory of black and organic carbon emissions from combustion. Journal of Geophysical Research, 109, D14203. https://doi.org/10.1029/2003JD003697

Bond, T. C., Bhardwaj, E., Dong, R., Jogani, R., Jung, S., Roden, C., et al. (2007). Historical emissions of black and organic carbon aerosol from energy-related combustion, 1850-2000. Global Biogeochemical Cycles, 21, GB2018. https://doi.org/10.1029/2006GB002840

Bond, T. C., Doherty, S. J., Fahey, D. W., Forster, P. M., Berntsen, T., DeAngelo, B. J., et al. (2013). Bounding the role of black carbon in the climate system: A scientific assessment: Black carbon in the climate system. Journal of Geophysical Research: Atmospheres, 118, 5380-5552. https://doi.org/10.1002/jgrd.50171

Cottle, P., Strawbridge, K., McKendry, I., O'Neill, N., \& Saha, A. (2013). A pervasive and persistent Asian dust event over North America during spring 2010: Lidar and sunphotometer observations. Atmospheric Chemistry and Physics, 13(9), 4515-4527. https://doi.org/ 10.5194/acp-13-4515-2013

Crusius, J., Schroth, A. W., Gassó, S., Moy, C. M., Levy, R. C., \& Gatica, M. (2011). Glacial flour dust storms in the Gulf of Alaska: Hydrologic and meteorological controls and their importance as a source of bioavailable iron: Glacial flour dust in Gulf of Alaska. Geophysical Research Letters, 38, L06602. https://doi.org/10.1029/2010GL046573

Doherty, S. J., Warren, S. G., Grenfell, T. C., Clarke, A. D., \& Brandt, R. E. (2010). Light-absorbing impurities in Arctic snow. Atmospheric Chemistry and Physics, 10(23), 11647-11680. https://doi.org/10.5194/acp-10-11647-2010, https://doi.org/10.5194/acp-10-11647-2010

Doherty, S. J., Grenfell, T. C., Forsström, S., Hegg, D. L., Brandt, R. E., \& Warren, S. G. (2013). Observed vertical redistribution of black carbon and other insoluble light-absorbing particles in melting snow: Melt redistribution of BC in snow. Journal of Geophysical Research: Atmospheres, 118, 5553-5569. https://doi.org/10.1002/jgrd.50235

Flanner, M. G., Zender, C. S., Hess, P. G., Mahowald, N. M., Painter, T. H., Ramanathan, V., \& Rasch, P. J. (2009). Springtime warming and reduced snow cover from carbonaceous particles. Atmospheric Chemistry and Physics, 9(7), 2481-2497. https://doi.org/10.5194/acp-92481-2009

Flanner, M. G., Zender, C. S., Randerson, J. T., \& Rasch, P. J. (2007). Present-day climate forcing and response from black carbon in snow. Journal of Geophysical Research, 112, D11202. https://doi.org/10.1029/2006JD008003

Gabbi, J., Huss, M., Bauder, A., Cao, F., \& Schwikowski, M. (2015). The impact of Saharan dust and black carbon on albedo and long-term mass balance of an Alpine glacier. The Cryosphere, 9(4), 1385-1400. https://doi.org/10.5194/tc-9-1385-2015

Ganey, G. Q., Loso, M. G., Burgess, A. B., \& Dial, R. J. (2017). The role of microbes in snowmelt and radiative forcing on an Alaskan icefield. Nature Geoscience, 10(10), 754-759. https://doi.org/10.1038/ngeo3027

Gardner, A. S., Moholdt, G., Cogley, J. G., Wouters, B., Arendt, A. A., Wahr, J., et al. (2013). A reconciled estimate of glacier contributions to sea level rise: 2003 to 2009. Science, 340(6134), 852-857. https://doi.org/10.1126/science.1234532

Goelles, T., \& Bøggild, C. E. (2017). Albedo reduction of ice caused by dust and black carbon accumulation: A model applied to the Ktransect, West Greenland. Journal of Glaciology, 63(242), 1063-1076. https://doi.org/10.1017/jog.2017.74

Hadley, O. L., Corrigan, C., \& Ramanathan, V. (2007). Measurements of black carbon in California snow and rain (No. CEC-500-2008-029). California Energy Commission, PIER Energy-Related Environmental Research Program. Retrieved from http://www.energy.ca.gov/ 2008publications/CEC-500-2008-029/CEC-500-2008-029.PDF

Hadley, O. L., \& Kirchstetter, T. W. (2012). Black-carbon reduction of snow albedo. Nature Climate Change, 2(6), 437-440. https://doi.org/ $10.1038 /$ nclimate1433

Hansen, J., \& Nazarenko, L. (2004). Soot climate forcing via snow and ice albedos. Proceedings of the National Academy of Sciences, 101(2), 423-428. https://doi.org/10.1073/pnas.2237157100

Holland, M. M., Bitz, C. M., \& Tremblay, B. (2006). Future abrupt reductions in the summer Arctic Sea ice. Geophysical Research Letters, 33, L23503. https://doi.org/10.1029/2006GL028024 
Jaffe, D., McKendry, I., Anderson, T., \& Price, H. (2003). Six 'new' episodes of trans-Pacific transport of air pollutants. Atmospheric Environment, 37(3), 391-404. https://doi.org/10.1016/S1352-2310(02)00862-2

Kaspari, S., Painter, T. H., Gysel, M., Skiles, S. M., \& Schwikowski, M. (2014). Seasonal and elevational variations of black carbon and dust in snow and ice in the Solu-Khumbu, Nepal and estimated radiative forcings. Atmospheric Chemistry and Physics, 14(15), 8089-8103. https://doi.org/10.5194/acp-14-8089-2014

Kaspari, S. D., Schwikowski, M., Gysel, M., Flanner, M. G., Kang, S., Hou, S., \& Mayewski, P. A. (2011). Recent increase in black carbon concentrations from a Mt. Everest ice core spanning 1860-2000 AD. Geophysical Research Letters, 38, D15206. https://doi.org/10.1029/ 2010GL046096

Kaspari, S. D., Skiles, S. M., Delaney, I., Dixon, D., \& Painter, T. H. (2015). Accelerated glacier melt on Snow Dome, Mount Olympus, Washington, USA, due to deposition of black carbon and mineral dust from wildfire. Journal of Geophysical Research: Atmospheres, 120, 2793-2807. https://doi.org/10.1002/2014JD022676

Knelman, J. E., Legg, T. M., O'Neill, S. P., Washenberger, C. L., González, A., Cleveland, C. C., \& Nemergut, D. R. (2012). Bacterial community structure and function change in association with colonizer plants during early primary succession in a glacier forefield. Soil Biology and Biochemistry, 46, 172-180. https://doi.org/10.1016/j.soilbio.2011.12.001

Koch, D. (2005). Distant origins of Arctic black carbon: A Goddard Institute for Space Studies ModelE experiment. Journal of Geophysical Research, 110, D04204. https://doi.org/10.1029/2004JD005296

Larsen, C. F., Burgess, E., Arendt, A. A., O'Neel, S., Johnson, A. J., \& Kienholz, C. (2015). Surface melt dominates Alaska glacier mass balance. Geophysical Research Letters, 42, 5902-5908. https://doi.org/10.1002/2015GL064349

Lertzman, K. P., Gavin, D., Hallett, D., Brubaker, L., Lepofsky, D., \& Mathews, R. (2002). Long-term fire regime estimated from soil charcoal in coastal temperate rainforests. Ecology and Society, 6, 5.

Libois, Q., Picard, G., France, J. L., Arnaud, L., Dumont, M., Carmagnola, C. M., \& King, M. D. (2013). Influence of grain shape on light penetration in snow. The Cryosphere, 7, 1803-1818. https://doi.org/10.5194/tc-7-1803-2013

Mahowald, N. M., Kloster, S., Engelstaedter, S., Moore, J. K., Mukhopadhyay, S., McConnell, J. R., et al. (2010). Observed 20th century desert dust variability: Impact on climate and biogeochemistry. Atmospheric Chemistry and Physics, 10(22), 10,875-10,893. https://doi. org/10.5194/acp-10-10875-2010

McConnell, J. R., Edwards, R., Kok, G. L., Flanner, M. G., Zender, C. S., Saltzman, E. S., et al. (2007). 20th-century industrial black carbon emissions altered Arctic climate forcing. Science, 317(5843), 1381-1384. https://doi.org/10.1126/science.1144856

Miller, M. M., \& Pelto, M. S. (1999). Mass balance measurements on the Lemon Creek Glacier, Juneau Icefield, Alaska 1953-1998. Geografiska Annaler, Series A: Physical Geography, 81(4), 671-681. https://doi.org/10.1111/1468-0459.00095

Motyka, R. J., O'Neel, S., Connor, C. L., \& Echelmeyer, K. A. (2003). Twentieth century thinning of Mendenhall Glacier, Alaska, and its relationship to climate, lake calving, and glacier run-off. Global and Planetary Change, 35(1-2), 93-112. https://doi.org/10.1016/S09218181(02)00138-8

Neff, P. D., Steig, E. J., Clark, D. H., McConnell, J. R., Pettit, E. C., \& Menounos, B. (2012). Ice-core net snow accumulation and seasonal snow chemistry at a temperate-glacier site: Mount Waddington, southwest British Columbia, Canada. Journal of Glaciology, 58(212), 1165-1175. https://doi.org/10.3189/2012JoG12J078

Oerlemans, J., Giesen, R. H., \& van den Broeke, M. R. (2009). Retreating alpine glaciers: Increased melt rates due to accumulation of dust (Vadret da Morteratsch, Switzerland). Journal of Glaciology, 55(192), 729-736. https://doi.org/10.3189/002214309789470969

Painter, T. H., Flanner, M. G., Kaser, G., Marzeion, B., VanCuren, R. A., \& Abdalati, W. (2013). End of the Little Ice Age in the Alps forced by industrial black carbon. Proceedings of the National Academy of Sciences, 110(38), 15216-15221. https://doi.org/10.1073/ pnas. 1302570110

Painter, T. H., Skiles, S. M., Deems, J. S., Brandt, W. T., \& Dozier, J. (2018). Variation in rising limb of Colorado River snowmelt runoff hydrograph controlled by dust radiative forcing in snow. Geophysical Research Letters, 45, 797-808. https://doi.org/10.1002/ 2017GL075826

Qian, Y., Yasunari, T. J., Doherty, S. J., Flanner, M. G., Lau, W. K. M., Ming, J., et al. (2015). Light-absorbing particles in snow and ice: Measurement and modeling of climatic and hydrological impact. Advances in Atmospheric Sciences, 32(1), 64-91. https://doi.org/ 10.1007/s00376-014-0010-0

Qu, B., Ming, J., Kang, S.-C., Zhang, G.-S., Li, Y.-W., Li, C.-D., et al. (2014). The decreasing albedo of the Zhadang glacier on western Nyainqentanglha and the role of light-absorbing impurities. Atmospheric Chemistry and Physics, 14(20), 11,117-11,128. https://doi.org/ 10.5194/acp-14-11117-2014

Radić, V., Bliss, A., Beedlow, A. C., Hock, R., Miles, E., \& Cogley, J. G. (2014). Regional and global projections of twenty-first century glacier mass changes in response to climate scenarios from global climate models. Climate Dynamics, 42(1-2), 37-58. https://doi.org/10.1007/ s00382-013-1719-7

Rain Coast Data. (2018). Southeast Alaska by the numbers, 2018 (p. 16). Souhteast Conference. Retrieved from http://www.raincoastdata com/portfolio/southeast-alaska-numbers-2018

Ramanathan, V., \& Carmichael, G. (2008). Global and regional climate changes due to black carbon. Nature Geoscience, 1(4), $221-227$. https://doi.org/10.1038/ngeo156

Ricchiazzi, P., Yang, S., Gautier, C., \& Sowle, D. (1998). SBDART: A research and teaching software tool for plane-parallel radiative transfer in the Earth's atmosphere. Bulletin of the American Meteorological Society, 79(10), 2101-2114. https://doi.org/10.1175/15200477(1998)079<2101:SARATS>2.0.CO;2

Schmale, J., Flanner, M., Kang, S., Sprenger, M., Zhang, Q., Guo, J., et al. (2017). Modulation of snow reflectance and snowmelt from Central Asian glaciers by anthropogenic black carbon. Scientific Reports, 7(1). https://doi.org/10.1038/srep40501

Schwarz, J. P., Doherty, S. J., Li, F., Ruggiero, S. T., Tanner, C. E., Perring, A. E., et al. (2012). Assessing single particle soot photometer and integrating sphere/integrating sandwich spectrophotometer measurement techniques for quantifying black carbon concentration in snow. Atmospheric Measurement Techniques, 5(11), 2581-2592. https://doi.org/10.5194/amt-5-2581-2012

Schwarz, J. P., Gao, R. S., Perring, A. E., Spackman, J. R., \& Fahey, D. W. (2013). Black carbon aerosol size in snow. Scientific Reports, 3(1), 1356. https://doi.org/10.1038/srep01356

Shanley, C. S., Pyare, S., Goldstein, M. I., Alaback, P. B., Albert, D. M., Beier, C. M., et al. (2015). Climate change implications in the northern coastal temperate rain forest of North America. Climatic Change, 130(2), 155-170. https://doi.org/10.1007/s10584-015$1355-9$

Sigl, M., Abram, N. J., Gabrieli, J., Jenk, T. M., Osmont, D., \& Schwikowski, M. (2018). 19th century glacier retreat in the Alps preceded the emergence of industrial black carbon deposition on high-alpine glaciers. The Cryosphere, 12(10), 3311-3331. https://doi.org/10.5194/tc$12-3311-2018$ 
Skiles, S. M., Flanner, M., Cook, J. M., Dumont, M., \& Painter, T. H. (2018). Radiative forcing by light-absorbing particles in snow. Nature Climate Change, 8(11), 964-971. https://doi.org/10.1038/s41558-018-0296-5

Skiles, S. M., Painter, T., \& Okin, G. S. (2017). A method to retrieve the spectral complex refractive index and single scattering optical properties of dust deposited in mountain snow. Journal of Glaciology, 63(237), 133-147. https://doi.org/10.1017/jog.2016.126

Skiles, S. M., \& Painter, T. H. (2017). Daily evolution in dust and black carbon content, snow grain size, and snow albedo during snowmelt, Rocky Mountains, Colorado. Journal of Glaciology, 63(237), 118-132. https://doi.org/10.1017/jog.2016.125

Skiles, S. M., Painter, T. H., Belnap, J., Holland, L., Reynolds, R. L., Goldstein, H. L., \& Lin, J. (2015). Regional variability in dust-on-snow processes and impacts in the Upper Colorado River Basin: Dust-on-snow spatial variability. Hydrological Processes, 29(26), 5397-5413. https://doi.org/10.1002/hyp.10569

Skiles, S. M., Painter, T. H., Deems, J. S., Bryant, A. C., \& Landry, C. C. (2012). Dust radiative forcing in snow of the Upper Colorado River Basin: 2. Interannual variability in radiative forcing and snowmelt rates. Water Resources Research, 48, W07522. https://doi.org/10.1029/ 2012WR011986

Stephens, M., Turner, N., \& Sandberg, J. (2003). Particle identification by laser-induced incandescence in a solid-state laser cavity. Applied Optics, 42(19), 3726. https://doi.org/10.1364/AO.42.003726

Sterle, K. M., McConnell, J. R., Dozier, J., Edwards, R., \& Flanner, M. G. (2012). Retention and radiative forcing of black carbon in Eastern Sierra Nevada snow. The Cryosphere, 6(3), 2247-2264. https://doi.org/10.5194/tcd-6-2247-2012

Stubbins, A., Hood, E., Raymond, P. A., Aiken, G. R., Sleighter, R. L., Hernes, P. J., et al. (2012). Anthropogenic aerosols as a source of ancient dissolved organic matter in glaciers. Nature Geoscience, 5(3), 198-201. https://doi.org/10.1038/ngeo1403

Takeuchi, N. (2009). Temporal and spatial variations in spectral reflectance and characteristics of surface dust on Gulkana Glacier, Alaska Range. Journal of Glaciology, 55(192), 701-209. https://doi.org/10.3189/002214309789470914

Takeuchi, N., Dial, R., Kohshima, S., Segawa, T., \& Uetake, J. (2006). Spatial distribution and abundance of red snow algae on the Harding Icefiled, Alaska derived from a satellite image. Geophysical Research Letters, 33, L21502. https://doi.org/10.1029/2006GL027819

Tedesco, M., Doherty, S., Fettweis, X., Alexander, P., Jeyaratnam, J., \& Stroeve, J. (2016). The darkening of the Greenland ice sheet: Trends, drivers, and projections (1981-2100). The Cryosphere, 10(2), 477-496. https://doi.org/10.5194/tc-10-477-2016

Tegen, I., Lacis, A. A., \& Fung, I. (1996). The influence on climate forcing of mineral aerosols from disturbed soils. Nature, 380(6573), 419-422. https://doi.org/10.1038/380419a0

Thomas, J. L., Polashenski, C. M., Soja, A. J., Marelle, L., Casey, K. A., Choi, H. D., et al. (2017). Quantifying black carbon deposition over the Greenland ice sheet from forest fires in Canada. Geophysical Research Letters, 44, 7965-7974. https://doi.org/10.1002/2017GL073701

Tuzet, F., Dumont, M., Lafaysse, M., Picard, G., Arnaud, L., Voisin, D., et al. (2017). A multilayer physically based snowpack model simulating direct and indirect radiative impacts of light-absorbing impurities in snow. The Cryosphere, 11(6), 2633-2653. https://doi.org/ $10.5194 / \mathrm{tc}-11-2633-2017$

Warren, S., \& Wiscombe, W. (1980). A model for the spectral albedo of snow. 2. Snow containing atmospheric aerosols. Journal of Atmospheric Sciences, 37(12), 2734-2745. https://doi.org/10.1175/1520-0469(1980)037<2734:AMFTSA>2.0.CO;2

Warren, S. G., \& Brandt, R. E. (2008). Optical constants of ice from the ultraviolet to the microwave: A revised compilation. Journal of Geophysical Research, 113, D14220. https://doi.org/10.1029/2007JD009744

Wendl, I. A., Menking, J. A., Färber, R., Gysel, M., Kaspari, S. D., Laborde, M. J. G., \& Schwikowski, M. (2014). Optimized method for black carbon analysis in ice and snow using the single particle soot photometer. Atmospheric Measurement Techniques, 7(8), 2667-2681. https://doi.org/10.5194/amt-7-2667-2014

Wittmann, M., Groot Zwaaftink, C. D., Steffensen Schmidt, L., Guðmundsson, S., Pálsson, F., Arnalds, O., et al. (2017). Impact of dust deposition on the albedo of Vatnajökull ice cap, Iceland. The Cryosphere, 11(2), 741-754. https://doi.org/10.5194/tc-11-741-2017

Xu, B., Cao, J., Hansen, J., Yao, T., Joswia, D. R., Wang, N., et al. (2009). Black soot and the survival of Tibetan glaciers. Proceedings of the National Academy of Sciences, 106(52), 22114-22118. https://doi.org/10.1073/pnas.0910444106

Yasunari, T. J., Bonasoni, P., Laj, P., Fujita, K., Vuillermoz, E., Marinoni, A., et al. (2010). Estimated impact of black carbon deposition during pre-monsoon season from Nepal Climate Observatory - Pyramid data and snow albedo changes over Himalayan glaciers. Atmospheric Chemistry and Physics, 10(14), 6603-6615. https://doi.org/10.5194/acp-10-6603-2010

Yi, B., Yang, P., \& Baum, B. A. (2014). Impact of pollution on the optical properties of trans-Pacific East Asian dust from satellite and ground-based measurements: Impact of pollution on dust properties. Journal of Geophysical Research: Atmospheres, 119, 5397-5409. https://doi.org/10.1002/2014JD021721

Yu, H., Remer, L. A., Chin, M., Bian, H., Kleidman, R. G., \& Diehl, T. (2008). A satellite-based assessment of transpacific transport of pollution aerosol. Journal of Geophysical Research, 113, D14S12. https://doi.org/10.1029/2007JD009349

Yu, H., Remer, L. A., Chin, M., Bian, H., Tan, Q., Yuan, T., \& Zhang, Y. (2012). Aerosols from overseas rival domestic emissions over North America. Science, 337(6094), 566-569. https://doi.org/10.1126/science.1217576

Zhang, X. Y., Gong, S. L., Zhao, T. L., Arimoto, R., Wang, Y. Q., \& Zhou, Z. J. (2003). Sources of Asian dust and role of climate change versus desertification in Asian dust emission: Asian dust sources. Geophysical Research Letters, 30(24), 2272. https://doi.org/10.1029/ 2003GL018206

Ziemen, F. A., Hock, R., Aschwanden, A., Khroulev, C., Kienholz, C., Melkonian, A., \& Zhang, J. (2016). Modeling the evolution of the Juneau Icefield between 1971 and 2100 using the parallel ice sheet model (PISM). Journal of Glaciology, 62(231), 199-214. https://doi. org/10.1017/jog.2016.13 